\title{
Pomiar i analiza absencji pracowniczej
}

\author{
MAEGORZATA STRIKer \\ Katedra Zarządzania Zasobami Ludzkimi, Uniwersytet Łódzki
}

\begin{abstract}
Mierniki dotyczące poziomu absencji są wymieniane wśród informacji wykorzystywanych do oceny efektywności procesów zarządzania zasobami ludzkimi w organizacji i stopnia wykorzystania zaangażowanego kapitału ludzkiego. Celem niniejszego artykułu jest przedstawienie na podstawie przeprowadzonej analizy studiów literaturowych stosowanych rozwiązań w zakresie pomiaru i analizy absencji pracowniczej na poziomie organizacji. Rozważania podzielono na cztery części. W pierwszej skoncentrowano się na omówieniu źródeł informacji do pomiaru i analizy absencji. Kolejne trzy dotyczą mierzenia i analizowania odpowiednio: poziomu absencji, jej przyczyn i kosztów.
\end{abstract}

Słowa kluczowe: zarządzanie absencją, koszty absencji, przyczyny absencji, pomiar absencji.

\section{Wstęp}

Dostęp do informacji o zasobach ludzkich organizacji (Human Resource Information HRI) jest obecnie określany jako priorytetowy problem zarówno dla praktyków, jak i badaczy z zakresu zarządzania zasobami ludzkimi. Jakość dostępnych informacji dla menadżerów liniowych i kadry kierowniczej wyższego szczebla nie jest zadowalająca. Widoczna jest luka w wiedzy na temat atrybutów, jakie powinny spełniać gromadzone i przetwarzane informacje o zasobach ludzkich, żeby mogły być postrzegane jako skuteczne i użyteczne w procesie podejmowania decyzji (Winkler i in. 2013, s. 227). Mierniki dotyczące poziomu absencji są wymieniane wśród informacji stosowanych do oceny efektywności procesów zarządzania zasobami ludzkimi w organizacji i stopnia wykorzystania zaangażowanego kapitału ludzkiego (Baron, Armstrong, 2008, s. 82; Łukasiewicz, 2009, s. 121-123). Pomimo, że absencja oceniana jest jako zjawisko dość łatwo poddające się pomiarowi, w praktyce podobnie jak i inne miary służące wycenie ZZL, stosowana jest stosunkowo rzadko. Badania prowadzone w Wielkiej Brytanii ujawniły, że niespełna połowa przedsiębiorstw monitoruje poziom absencji (Kownacka, 
2013). W Polsce sytuacja wygląda jeszcze gorzej, niecałe $37 \%$ firm deklaruje, że wykorzystuje w procesie zarządzania wskaźniki dotyczące fluktuacji i absencji (Sienkiewicz, 2013, s. 171). Powyższe przesłanki spowodowały, że celem niniejszego artykułu stało się przedstawienie, na podstawie przeprowadzonej analizy studiów literaturowych, stosowanych rozwiązań w zakresie pomiaru i analizy wielkości absencji pracowniczej na poziomie organizacji. Rozważania podzielono na cztery części. W pierwszej skoncentrowano się na omówieniu źródeł informacji do pomiaru i analizy absencji. Kolejne trzy dotyczą mierzenia i analizowania odpowiednio: poziomu absencji, jej przyczyn i kosztów.

\section{1. Źródła danych do pomiaru i analizy absencji pracowniczej}

Absencja jest zjawiskiem, które stosunkowo łatwo jest zmierzyć i jednocześnie wywołującym duże zainteresowanie społeczne, z uwagi na wysokość generowanych kosztów zarówno na poziomie makroekonomicznym, jak i mikro- dla pracodawców i pracowników. Powoduje to, że badane jest z punktu widzenia wielu dyscyplin naukowych, między innymi: psychologii, socjologii, ekonomii, zarządzania, medycyny, rehabilitacji, prawa, zdrowia publicznego, ergonomii. Podstawowym problemem w zakresie pomiaru rozmiarów absencji podnoszonym przez badaczy jest fakt, że choć z zewnątrz absencja wydaje się jednolitym zjawiskiem nie jest takim w istocie. Wynika to przede wszystkim z dużej różnorodności przyczyn ją wywołujących. Dodatkowym utrudnieniem jest również postrzeganie nieobecności w pracy jako zjawiska negatywnego, czasami wręcz dysfunkcjonalnego i społecznie niepożądanego. Skutkuje to niechęcią badanych podmiotów do ujawnienia faktycznego poziomu i przyczyn absencji.

W pomiarze absencji prowadzonym $w$ ramach nauk o zarządzaniu dominuje przetwarzanie danych o charakterze ilościowym, gromadzonych na poziomie poszczególnych jednostek organizacyjnych z wykorzystaniem kwestionariuszy ankietowych oraz systemów ewidencji czasu pracy. Tradycyjne podejście do badań absencji chorobowej wykorzystywane w dyscyplinach związanych z zarządzaniem zasobami ludzkimi i badaniem zachowań organizacyjnych, koncentruje się na poszukiwaniu korelacji pomiędzy trzema zmiennymi: wskaźnikiem demograficznym (wiek, płeć, staż pracy, wykształcenie), udzieloną odpowiedzią w kwestionariuszu oraz przypisanym danej osobie poziomem absencji. Taka metoda wykorzystywana jest do badania związków pomiędzy nieobecnością w pracy a zaangażowaniem, motywacją, czy satysfakcją z pracy. Prowadzone są również badania porównawcze wśród celowo zróżnicowanych grup, co pozwala zrozumieć jak rola społeczna, zawód, kultura narodowa lub płeć wpływa na obecność w pracy, jak menedżerowie i podwładni różnią się w swoich poglądach na temat 
nieobecności. Zdecydowanie najrzadziej do badania absencji w naukach o zarządzaniu wykorzystywane są eksperymenty. Celem tych nielicznych, które były prowadzone, była ocena konkretnych działań menedżerskich prowadzących do zmniejszenia poziomu absencji, np. kompleksowych programów wsparcia dla pracowników, dostarczania informacji zwrotnych, stosowania zachęt finansowych, czy wprowadzania zamian w regulaminach pracy. Oprócz dowodów na skuteczność programów zmniejszających absencję, eksperymenty dostarczają również wiedzy teoretycznej na temat czynników kształtujących zachowania pracowników. Większość badań prowadzonych jest w grupach wieloosobowych, a ich celem jest poszukiwanie zmiennych, które wyróżniają osoby o wysokim i niskim wskaźniku absencji. Co raz częściej w badaniach i analizie absencji wykorzystywane są również badania jakościowe - wywiady pogłębione i obserwacja (Johns 2003).

Podstawą rzetelnego pomiaru poziomu absencji jest dostęp do dokładnych i aktualnych informacji na temat nieobecności w pracy. Dość dużym ograniczeniem dla pracodawców i badaczy jest fakt, że gromadzone dane mają charakter danych wrażliwych, do których dostęp jest uzależniony od dobrej woli pracownika, dotyczy to zwłaszcza przyczyn nieobecności. W proponowanych zakresach zbieranych informacji (tabela 1) szczególną wagę przywiązuje się właśnie do tej ostatniej informacji. Przyczyna absencji pojawia się tu aż trzykrotnie: jako wstępna przyczyna określona tuż po rozpoczęciu nieobecności, przyczyna formalna podana w dokumentacji oraz przyczyna określona podczas spotkania bezpośredniego przełożonego z pracownikiem po zakończeniu nieobecności.

Tabela 1. Minimalny zakres gromadzonych informacji dotyczący nieobecności

\begin{tabular}{|l|}
\hline Po rozpoczęciu nieobecności: \\
\hline Imię i nazwisko, stanowisko, dział, wiek, płeć \\
\hline Data pierwszego dnia absencji \\
\hline Spodziewana data powrotu \\
\hline Wstępna przyczyna absencji \\
\hline Stwierdzenie, czy absencja jest związana z warunkami pracy \\
\hline Stwierdzenie czy nieobecność jest usprawiedliwiona \\
\hline Po zakończeniu nieobecności: \\
\hline data ostatniego dnia nieobecności \\
\hline liczba dni lub godzin nieobecności \\
\hline formalna przyczyna nieobecności \\
\hline $\begin{array}{l}\text { przyczyna nieobecności określona podczas spotkania z bezpośrednim przełożonym po } \\
\text { powrocie do pracy }\end{array}$ \\
\hline
\end{tabular}

Źródło: opracowanie własne na podstawie Measuring, Reporting and Costing Absence, 2007, s. 4-5. 
Najczęściej wskazywanym źródłem informacji pozwalającym na poznanie rzeczywistych przyczyn absencji konkretnego pracownika jest rozmowa $z$ bezpośrednim przełożonym zaraz po powrocie pracownika do pracy. Jej celem nie powinno być dyscyplinowanie podwładnego, ale wyjaśnienie przyczyn nieobecności i pomoc w rozwiązaniu problemu (Beesley, 2013). Yorges uważa, że wywiad po zakończeniu absencji jest jednym z najskuteczniejszych i stosunkowo tanim narzędziem zarządzania krótkotrwałą absencją. Z jednej strony pokazuje pracownikowi zaangażowanie kierownictwa w problem, pozwala lepiej poznać powody nieobecności oraz sprawdzić, czy pracownik czuje się na tyle dobrze, żeby wrócić do pracy. Celem takiej rozmowy jest budowanie otwartej relacji z podwładnym oraz oferowanie w razie potrzeby pomocy. Pracownicy zazwyczaj doceniają możliwość wyjaśnienia prawdziwych przyczyn nieobecności. Menedżer może też wykorzystać rozmowę do pokazania skutków, jakie dla działu miała nieobecność, na ile wpłynęła na pracę pozostałych pracowników. Pracownik powracający do pracy powinien też zostać poinformowany o aktualnej sytuacji - priorytetowych zadaniach, pracach, które zostały już wykonane. Wywiad, jeśli ma być źródłem wiarygodnych informacji, nie może być traktowany przez pracowników jako kara.

\section{Pomiar i analiza poziomu absencji pracowniczej}

Wyniki prowadzonych badań wskazują, że posiadanie przez menedżerów odpowiednich informacji o nieobecnościach w pracy jest jednym z głównych czynników w skutecznym rozwiązywaniu problemów absencji pracowniczej. Jeśli organizacja dysponuje wystarczająco dokładnymi informacjami na ten temat może wykorzystać je między innymi do: (1) zrozumienia przyczyn nieobecności oraz określenia tendencji i wzorców w korzystaniu ze zwolnień, (2) priorytetowym traktowaniu działań wobec tych pracowników, zespołów i wydziałów, które mają najwyższy poziom absencji, (3) wprowadzeniu tzw. trigersów, czyli automatycznie wykonywanych procedur z zakresu zarządzania zasobami ludzkimi w reakcji na historię nieobecności poszczególnych pracowników, (4) dostarczaniu informacji zwrotnych dla pracowników i menedżerów, (5) szacowania korzyści z wprowadzenia strategii zarządzania absencją np. redukcji stresu w miejscu pracy, (6) szacowania kosztów absencji, (7) stosowania zewnętrznego i wewnętrznego benchmarkingu w ocenie poziomu absencji. Niestety wiele organizacji nie mierzy absencji odpowiednio, co oznacza, że nie może wiarygodnie użyć gromadzonych danych do praktyki zarządzania absencją, jak i wyceny wartości posiadanego kapitału ludzkiego (Measuring ..., 2007, s. 2). 
Do pomiaru poziomu absencji pracowniczej wykorzystywane są cztery podstawowe wskaźniki: wskaźnik absencji (stopa absencji), wskaźnik częstotliwości absencji, średni czas trwania nieobecności oraz wskaźnik Bradforda (Tabela 2).

Tabela 2. Podstawowe miary poziomu absencji

\begin{tabular}{|c|l|l|}
\hline Lp. & \multicolumn{1}{|c|}{ Wskaźnik } & \multicolumn{1}{c|}{ Sposób wyliczenia } \\
\hline 1 & $\begin{array}{l}\text { Wskaźnik absencji (stopa } \\
\text { absencji }\end{array}$ & $\begin{array}{l}\text { procent nieobecności w całkowitym nominalnym czasie } \\
\text { pracy (nieobecności w godzinach lub dniach/całkowity } \\
\text { nominalny czas pracy w godzinach lub dniach) }\end{array}$ \\
\hline 2 & $\begin{array}{l}\text { Wskaźnik częstotliwości } \\
\text { nieobecności }\end{array}$ & $\begin{array}{l}\text { wyliczany jest w dwóch wariantach: } \\
\text { (1) liczba nieobecności zgłoszonych w okresie/średnia } \\
\text { liczba pracowników w okresie } \\
(2) \text { liczba pracowników, którzy mieli co najmniej jedno } \\
\text { zgłoszenie nieobecności/średnia liczba pracowników } \\
\text { w okresie }\end{array}$ \\
\hline 3 & $\begin{array}{l}\text { Średni czas trwania } \\
\text { nieobecności }\end{array}$ & $\begin{array}{l}\text { ogólny czas trwania nieobecności zgłoszonych w danym } \\
\text { okresie/liczba zgłoszonych nieobecności }\end{array}$ \\
\hline 4 & Wskaźnik Bradforda & $\begin{array}{l}\text { liczony jest według wzoru: } \mathrm{S} \times \mathrm{S} \times \mathrm{D} \text {, gdzie } \mathrm{S}-\text { liczba } \\
\text { zgłoszonych nieobecności, D }- \text { łączny czas trwania } \\
\text { zgłoszonych nieobecności. }\end{array}$ \\
\hline
\end{tabular}

Źródło: opracowanie własne na podstawie: Measuring, Reporting and Costing Absence 2007 s. 8-11; Martin (2010, s. 5-6).

Ilościowy pomiar absencji pracowniczej przy wykorzystaniu tych wskaźników może być dokonywany w odniesieniu do całej organizacji, jej części (działu, departamentu, oddziału), grup pracowników, lub konkretnej osoby.

Najczęściej stosowanym miernikiem jest wskaźnik absencji (stopa absencji). Jest łatwy do wyliczenia i właściwe nie budzi kontrowersji, jednak nie daje żadnych informacji o strukturze nieobecności, np. o tym czy jego wielkość wynika z dużej liczby krótkotrwałych nieobecności, czy kilku nieobecności długoterminowych. Aby w pełni zrozumieć naturę absencji organizacje powinny mierzyć częstotliwość i czas trwania nieobecności (Measuring... 2007, s. 8).

Wskaźnik częstotliwości nieobecności pokazuje ile średnio nieobecności przypada na jednego pracownika (wariant 1) lub jaki procent pracowników miało co najmniej jedno zwolnienie (wariant 2). Słabością tej miary jest to, że każdą nieobecność traktuje tak samo bez względu na czas jej trwania, np. jednodniową i tę trwającą cały miesiąc. Pomniejsza zatem wagę nieobecności długoterminowych.

Jednak najwięcej kontrowersji wywołuje ostatni $z$ wymienionych mierników: wskaźnik Bradforda. Łączy on informacje o częstotliwości i czasie trwania nieobecności. Stosowany jest w celu identyfikacji tych absencji, które powodują 
największe zakłócenia w organizacji; im wyższy wynik tym dana grupa nieobecności wywołuje większe komplikacje dla organizacji. Konstrukcja tego miernika wskazuje, że z punktu widzenia organizacji zdecydowanie gorszy jest sam fakt wystąpienia nieobecności niż czas jej trwania. Został on opracowany jako sposób na podkreślenie nieproporcjonalnego poziomu zakłóceń w wydajności pracy, powodowanych przez krótkoterminowe nieobecności w porównaniu do pojedynczych przypadków dłuższych nieobecności. Wykorzystanie wskaźnika Bradforda w odniesieniu do całej organizacji pozwala wskazać, które nieobecności sprawiają w firmie największe kłopoty. Analizuje się wtedy wszystkie absencje, grupując je według czasu trwania. Przykład wyliczenia wskaźników Bradforda dla wszystkich nieobecności w danej organizacji pokazany jest w Tabeli 3.

Tabela 3. Przykład wyliczenia wskaźników Bardforda dla całej organizacji

\begin{tabular}{|c|c|c|c|}
\hline $\begin{array}{c}\text { długość trwania poje- } \\
\text { dynczej absencji }\end{array}$ & $\begin{array}{c}\text { liczba wystąpień } \\
\text { absencji w okresie (S) }\end{array}$ & $\begin{array}{c}\text { czas trwania absencji } \\
\text { (D) }\end{array}$ & wskaźnik Bradforda \\
\hline 1 & 10 & 10 & 1000 \\
\hline 2 & 3 & 6 & 54 \\
\hline 3 & 15 & 45 & 10125 \\
\hline 5 & 17 & 85 & 24565 \\
\hline 6 & 10 & 60 & 6000 \\
\hline 10 & 12 & 120 & 17280 \\
\hline 13 & 5 & 65 & 1625 \\
\hline 14 & 7 & 98 & 4802 \\
\hline 16 & 3 & 48 & 1280 \\
\hline 20 & 4 & 80 & 30000 \\
\hline 30 & 10 & 300 & \\
\hline
\end{tabular}

Źródło: opracowanie własne.

Analiza uzyskanych wyników pozwala na wskazanie, że w tej organizacji kierownictwo powinno skoncentrować swoją uwagę na nieobecnościach o najwyższym wskaźniku Bradforda: długoterminowych (trwających 30 dni) i średnioterminowych (5 i 10 dniowych).

W praktyce najczęściej wskaźnik ten wykorzystywany jest do oceny nieobecności poszczególnych pracowników. Jeśli pracownik A w badanym okresie był trzy razy nieobecny i nieobecności trwały odpowiednio 5, 5 i 10 dni, to jego wskaźnik Bradforda wynosi $180(3 \times 3 \times 20)$. $Z$ kolei, jeśli pracownik B był w badanym okresie nieobecny jeden raz i jego absencja trwała 20 dni, to jego wskaźnik Bradforda wynosi $20(1 \times 1 \times 20)$. Organizacje najczęściej określają tzw. punkt krytyczny, po 
przekroczeniu którego służby HR podejmują stosowne działania. Menedżerowie HR chętnie stosują wskaźniki ilościowe automatycznie, jako „wyzwalacze - trigery" procedur dyscyplinujących pracowników. Prowadzi to do niezadowolenia pracowników, konfliktów z menedżerami HR i skarg. Stosowanie w firmach tego wskaźnika do oceny pracowników bardzo często wywołuje gorącą dyskusję (Protokół..., 2012). W każdym przypadku konieczne jest indywidualne badanie przyczyn nieobecności.

Z powodzeniem natomiast może być stosowany przez pracodawców do identyfikacji nieobecności, które wymagają dalszych analiz. Pozwala to na skoncentrowanie uwagi i środków finansowych na konkretnych przypadkach i pominięcie dużej liczby „zwykłych” nieobecności. Ocena wskaźnika Bradforda stosowana w powiązaniu z poprzednimi miarami pomaga w analizie trendów nieobecności. Na przykład, niska ocena Bradford i wysoki wskaźnik absencji wskazuje na niewielką liczbę pracowników z długoterminowymi nieobecnościami, podczas gdy wysoki wynik Bradford i niski wskaźnik absencji sugeruje, że istnieje niewielka liczba pracowników z częstymi nieobecnościami krótkoterminowymi. Ważne jest, że wyniki Bradford nie mogą być stosowane w izolacji. Ponieważ koncentrują się wyłącznie na krótkoterminowych absencjach, mogą łatwo odwrócić uwagę od problemów związanych z długoterminową nieobecnością. Dla wielu menedżerów redukcja uporczywych nieobecności krótkoterminowych jest podstawowym celem działania z uwagi na dość łatwą ich eliminację na przykład poprzez stosowanie środków karnych (zmniejszenie wynagrodzenia). Nieobecności długoterminowe wymagają więcej uwagi, wysiłku i czasu, aby zmniejszyć. Praktyka wskazuje, że długotrwałe nieobecności generują większe koszty (stanowiących do 70\%), w przypadku nieprawidłowego zarządzania; koszty nieobecności i nie powinny być ignorowane przez skupienie się wyłącznie na wskaźnikach Bradford i krótkoterminowych nieobecności (Measuring... 2007, s. 11).

Innym problemem w użyciu wyników wskaźnika Bradford jest to, że w praktyce są one często stosowane z założeniem, że wszystkie krótkoterminowe nieobecności są powodowane brakiem motywacji i zaangażowania, a nie obiektywną przyczyną. To założenie może powodować niesłuszne oskarżenie pracownika, który może czuć się niesprawiedliwie osądzony przez organizację. Po stronie plusów należy wymienić, że istnieją dowody, że zastosowanie wyników Bradford może rzeczywiście zniechęcać pracowników do nadużywania zwolnień, wskaźnik ten pełni wówczas rolę ostrzeżenia (Martin, 2010, s. 7).

W badaniach absencji poświęca się dość dużo uwagi na wypracowanie metod „oczyszczenia” miar absencji poprzez wyraźne wydzielenie nieobecności dobrowolnych (zależnych od woli pracownika) i tych niedobrowolnych np. wynikających z choroby czy problemów komunikacyjnych. Idealna, czysta miara absencji 
będzie zawierała tylko przypadki nieobecności wynikających z własnego wyboru pracownika. Taki czysty wskaźnik absencji może pozwolić na faktyczne analizowanie związku na przykład pomiędzy zadowoleniem z pracy a nieobecnościami. Te działania oczyszczające najczęściej opierały się na wykorzystywaniu systemów kodowania przyczyn absencji. Niestety w praktyce takie „wyczyszczenie” i skategoryzowanie przypadków absencji, chociaż dla każdego pracodawcy bardzo pożądane, jest niemożliwe (Steel 2003, s. 245).

Zebrane dane ilościowe są podstawą analizy absencji pracowniczej w przedsiębiorstwie, której celem jest ocena skali problemu zarówno w odniesieniu do całej organizacji, poszczególnych grup pracowników i konkretnych przypadków nieobecności. Identyfikacja głównych trendów związanych z absencją występujących w organizacji - wskazanie komórek organizacyjnych zagrożonych wysoką absencją, identyfikacja najważniejszych przyczyn absencji, na które organizacja może mieć wpływ np. zbyt wysoki poziom stresu, zła organizacja pracy, niski poziom bezpieczeństwa.

\section{Analiza przyczyn absencji pracowniczej}

Poziom absencji w pracy często postrzegany jest jako odzwierciedlenie ogólnego dobrobytu organizacji i osób w niej pracujących. Wskazuje się, że wysoka absencja może świadczyć o tym, że pracownicy w organizacji są dyskryminowani, prześladowani lub zbyt wiele się od nich wymaga, a kierownicy nie radzą sobie z zarządzaniem ludźmi. Determinanty składające się na poziom absencji są dość zróżnicowane i zalicza się do nich między innymi (Martin, 2010, s. 5): (1) treść i warunki pracy - poziom stresu, styl zarządzania, procedury stosowane $\mathrm{w}$ firmie, charakter i rodzaj umowy o pracę, normy organizacyjne lub grupowe w zakresie akceptowanego poziomu nieobecności, zwane kulturą nieobecności (Rentsch, Steel 2003), (2) wartości cenne dla pracownika: etyka pracy, poziom odpowiedzialności, (3) czynniki ekonomiczne - sytuacja gospodarcza, sytuacja na rynku pracy, polityka płacowa przedsiębiorstwa i inne rozwiązania motywacyjne, (4) cechy pracowników: wiek, płeć, wykształcenie, warunki rodzinne, osobowość, (5) obiektywne możliwości obecności - krótko i długookresowe choroby, wypadki przy pracy, obowiązki rodzinne, trudności komunikacyjne.

Wielu badaczy przywiązuje dość dużą wagę do analizy absencji pracowniczej z powodu przekonania, że poziom nieobecności w pracy świadczy o zaangażowaniu i motywacji pracowników, przez co pośrednio może stanowić podstawę do określenia wartości kapitału ludzkiego. Mierniki takie, jak liczba dni chorobowych wykorzystanych przez pracowników, czy średni liczba dni nieobecności 
przypadająca na pracownika stosowane są zarówno do pomiaru stanu kapitału ludzkiego, jak i efektów inwestycji w kapitał ludzki (Łukasiewicz, 2009). Fitz-Enz (2001, s. 169-170) wskazuje, że wzrost wskaźnika absencji może sygnalizować niezadowolenie pracowników. Publikowane wyniki nie są jednak jednoznaczne. Część z nich potwierdza, że absencja jest kształtowana przez pozytywne stany afektywne i dobre samopoczucie. Poczucie sensu pracy, które kształtuje poziom zaangażowania pracowników jest ujemnie skorelowane $\mathrm{z}$ poziomem absencji (Soane i in. 2013, s. 448-450).

Inne badania dowodzą, że brak autonomii w pracy, możliwości ustalania jej celów, możliwość uczenia się nowych, ciekawych rzeczy, to przyczyny spadku zaangażowania i wzrostu częstotliwości korzystania przez pracowników ze zwolnień lekarskich. Z kolei nadmierne wymagania pracy (przeciążenie pracą, presja czasu, konflikty, zakłócenie proporcji pomiędzy pracą a rodziną) są przyczyną pojawienia się wypalenia zawodowego, co wiąże się z wydłużaniem czasu nieobecności (Schaufeli i in. 2009, s. 897, 912). Również badania prowadzone przez Instytut Medycyny Pracy w Polsce (Szubert i in. 2009) dowodzą, że ryzyko absencji trwającej 30 dni i dłużej wzrasta niemal 2,5 krotnie w przypadkach bardzo silnego stresu wynikającego z psychospołecznych warunków pracy. Wtedy absencja jest jedną z przyjmowanych strategii radzenia sobie z niesprzyjającym środowiskiem pracy. Istotne jest więc nie tylko monitorowanie ogólnego poziomu absencji, ale zwracanie uwagi na jej cechy charakterystyczne, takie jak liczba pracowników korzystających ze zwolnień i czas trwania poszczególnych nieobecności. Inne działania powinny być podejmowane przez pracodawców w celu skrócenia czasu absencji, a inne jeżeli problemem jest częstotliwość korzystania ze zwolnień.

Publikowane są jednak również wyniki badań dowodzące, że absencja pracownicza jest zdecydowanie bardziej złożonym problemem. Ich autorzy przestrzegają przed prostym przeniesieniem uzyskanych wyników do praktyki (Hoxsey 2010, 567-568). Hipoteza mówiąca o tym, że w miarę wzrostu zaangażowania maleje poziom absencji nie została w pełni potwierdzona. Zdrowsi pracownicy nie zawsze są bardziej zaangażowani. Relacja pomiędzy tymi dwoma wartościami została zaburzona przez kilka zmiennych, takich jak: (1) wiek pracownika - wraz z wiekiem poziom absencji rośnie bez względu na poziom zaangażowania, (2) staż pracy - wraz ze wzrostem stażu pracy poziom korzystania ze zwolnień maleje oraz (3) płeć - kobiety częściej korzystają ze zwolnień, ale jednocześnie mają wyższe wskaźniki zaangażowania. Wśród kobiet wskaźnik zadowolenia z pracy w mniejszym stopniu determinuje wysokość absencji, która zależy przede wszystkim od poziomu obowiązków rodzinnych. Nawet jeśli dwoje rodziców pracuje, to uzgodnienia pomiędzy małżonkami najczęściej sprawiają, że w przypadku, np. choroby dziecka, to kobieta przejmuje obowiązek opieki i korzysta ze zwolnienia 
lekarskiego. Wpływ zaangażowania na poziom absencji powinien być więc rozpatrywany oddzielnie dla kobiet i mężczyzn. Potrzebnych jest również więcej badań, które będą koncentrowały się na odkrywaniu różnic w rozumieniu i odczuwaniu satysfakcji z pracy przez różne grupy pracowników.

\section{Pomiar i analiza kosztów absencji}

Absencja jest określona jako jedna z głównych przyczyn obniżenia wydajności pracy w przedsiębiorstwach w Wielkiej Brytanii (Baker-McClearn i in. 2010, s. 311). Koszty absencji ponoszone są jednak nie tylko przez pracodawców. Na poziomie ogółu społeczeństwa zalicza się do nich koszty zapewnienia opieki zdrowotnej, wypłaty zasiłków chorobowych oraz utratę dochodów z podatków. Dla innych członków zespołu wiążą się ze zwiększonym stresem, obniżonym morale, przepracowaniem osób niekorzystających ze zwolnień, obniżeniem jakości pracy w związku z koniecznością przejęcia dodatkowych, nie zawsze znanych obowiązków. Straty ponoszą też klienci firmy i związane mogą być one z niedotrzymanymi terminami, czy obniżoną jakością obsługi (Broadhead, 2008, s. 2).

Przy szacowaniu poziomu kosztów absencji w organizacji brane są pod uwagę zarówno koszty bezpośrednie, które stosunkowo łatwo określić na podstawie dokumentów płacowych i księgowych, jak i koszty pośrednie, które określane są przy wykorzystaniu zdecydowanie bardziej złożonych metod pomiaru. Do kosztów bezpośrednich zalicza się wynagrodzenie z tytułu nieobecności (np. wynagrodzenie chorobowe wypłacane w ciągu pierwszych trzydziestu dni zwolnienia lekarskiego) oraz koszty zastępstw (np. nadgodziny, zatrudnianie pracowników tymczasowych). Na koszty pośrednie składają się przede wszystkim koszty administracyjne związane z obsługą absencji, koszty czasu pracy kierowników liniowych poświęconego na zarządzanie absencją m.in. zorganizowanie zastępstw, nowy podział pracy oraz koszty obniżonej wydajności i jakości pracy (Broadhead 2008, s. 2).

Specjaliści z Chartered Institute of Personnel and Development (Measuring... 2007, s. 13-15) do kosztów zarządzania absencją zaliczyli również: koszty rozmów z powracającymi pracownikami, koszty szkoleń pozwalających na zastępowanie się wzajemne pracowników w ramach danego zespołu, koszty gromadzenia, przetwarzania i raportowania informacji o absencji, szkolenia dla menedżerów liniowych w zakresie kształtowania umiejętności zarządzania nieobecnościami.

Pomiar kosztów absencji pozwala na wskazanie nieobecności generujących dla pracodawcy największe straty. Nawet jeśli wskaźniki poziomu absencji są niskie, ponoszone koszty mogą okazać się dość wysokie, zwłaszcza jeśli związane są z długoterminowymi nieobecnościami. 


\section{Podsumowanie}

Cascio i Bourdeau wskazują, że analiza absencji pozwala na znalezienie odpowiedzi na kluczowe dla pracodawcy pytania: (1) czy absencja ma znaczenie w procesie pracy, np. czy dotyczy pracowników, którzy sami mogą ustalać swój czas pracy? (2) czy pracodawca ponosi z tytułu absencji znaczne koszty? czy inne osoby powinny wykonać pracę za osobę nieobecną? czy absencja przekłada się na obniżenie wydajności? czy występują opóźnienia w realizacji ważnych zadań? (3) jakie koszty ponosi pracodawca z tytułu absencji? (4) jaki program pozwoli obniżyć poziom absencji i jaki jest jego koszt (Cascio, Bourdeau 2011, s. 88). Jej wyniki będą determinowały dalsze działania, zmierzające do optymalizacji rozmiarów tego zjawiska. Zalicza się do nich między innymi: sprecyzowanie obowiązującej polityki absencji, rozmowy bezpośrednich przełożonych z podwładnymi po ich powrocie do pracy, podejmowanie działań dyscyplinujących oraz wprowadzanie programów eliminujących przyczyny nieobecności. Wszystkie one prowadzą do właściwego zarządzania absencją.

W badaniach nad absencją zauważyć również trzeba, że wiele ważnych czynników nie może zostać włączona do badań z uwagi na poufność i niedostępność informacji, np. dotyczących poziomu (stanu) zdrowia pracowników. Niewątpliwie absencja stanowi istotny element pomiaru wartości kapitału ludzkiego. Wykorzystywanie jednak tylko wskaźników ilościowych jest niewystarczające. Stosować należy bardziej wyrafinowane i skomplikowane modele wyjaśniające relację pomiędzy wartością kapitału a poziomem absencji. Nie można zadowolić się stwierdzeniem, że niezadowoleni pracownicy (niezaangażowani, niezmotywowani) są bardziej skłonni korzystać ze zwolnień. Ignoruje się bowiem w ten sposób obowiązek wyjaśnienia złożoności przyczyn absencji i jej wpływu na wartość kapitału ludzkiego.

\section{Bibliografia}

Baker-McClearn, D., Greasley, K., Dale J., Griffith, F. (2010), Absence management and resenteeism: the pressures on employees to attend work and the impact of attendance on performance, "Human Resource Management Journal", Vol. 20 No. 3.

Baron, A., Armstrong, M. (2008), Zarzq̨dzanie kapitałem ludzkim. Uzyskiwanie wartości dodanej dzięki ludziom, Oficyna Ekonomiczna, Kraków. 
Beesley, C., 7 Tips for Controlling and Preventing Employee Absenteeism, http://www.sba. gov/community/blogs/community-blogs/small-business-matters/7-tips-controlli ng-and-preventing-employee-ab [data dostępu: 11.04.2013]

Broadhead, J. (2008), How much is absenence costing your organization, "Human Resources" Juny/July.

Cascio, W., Boudreau, J. (2011), Inwestowanie w ludzi. Wpływ inicjatyw z zakresu ZZL na wyniki finansowe przedsiębiorstwa, Oficyna a Wolters Kluwer business, Warszawa.

Fitz-Enz, J. (2001), Rentowność inwestycji w kapitał ludzki, Oficyna Ekonomiczna, Kraków.

Hoxsey, D. (2010), Are happy employees healthy employees? Researching the effects of employee engagement on absenteeism, "Canadian Public Administration", Vol. 53 (4).

Johns, G. (2003), How methodological diversity has improved our understanding of absenteeism from work, "Human Resource Management Review", Vol. 13, Issue 2.

Kownacka, A. (2013), Absencja pracownicza - sposoby jej kontrolowania i zmniejszania, http://212.191.71.5/han/RynekpracyPL/rynekpracy.pl/artykul.php/typ.1/kategoria_glowna.9/wpis.658 [ data dostępu: 01.10.2013]

Łukasiewicz, G. (2009), Kapitał ludzki organizacji. Pomiar i sprawozdawczość, PWN, Warszawa.

Martin, J. (2010), Key concepts in human resource management, Sage 2010.

Measuring, Reporting and Costing Absence, (2007), www.cipd.co.uk_NR_rdonlyres_3A208F80-3484-4CE7-B8DD-907FFE660850_0_Wellbeing_sample_chapter_02 [data dostępu: 02.10.2013]

Protokół ze spotkania TNT Express Worldwide (Poland) Spółka z o.o. i Związku Zawodowego Pracowników Transportu, (2012), http://tntozzpt.home.pl/data/documents/ PROTOK=C3=93=C5=81=20ZE=20SPOTKANIE=2018=20 GRUDNIA=202012. PDF [data dostępu: 01.10.2013]

Rentsch, J.R., Steel, R.P. (2003), What does unit-level absence mean? Issues for future unit-level absence research, "Human Resource Management Review", Vol. 13, Issue 2.

Schaufeli, W.B., Bakker, A.B., Van Rhenen, W. (2009), How changes in job demands and resources predict burnout, work engagement, and sickness absenteeism, "Journal of Organizational Behavior", 30.

Soane, E., Shantz, A., Alfes, K., Truss, C., Rees, Ch., Gatenby, M. (2013), The Association of Meaningfulness, Well-Being, and Engagement With Absenteeism: A Moderated Mediation Model, "Human Resource Management", Vol. 52, No. 3.

Steel, R.P. (2003), Methodological and operational issues in the construction of absence variables, "Human Resource Management Review", Vol. 13, Issue 2.

Szubert, Z., Merecz-Kot, D., Sobala, W. (2009), Stres zawodowy a ryzyko absencji chorobowej na stanowiskach obsługi interesantów, „Medycyna Pracy”, Nr 60(4).

Winkler, S., König, C., Kleinmann, M. (2013), What makes human resource information successful? Managers' perceptions of attributes for successful human resource information, "International Journal of Human Resource Management", Vol. 24, Issue 2. 
Yorges, S., The Role of Supervisor in Managing Absenteeism, http://humanresources.about.com/od/laborrelations/a/manage_absences_2.htm Zarzadzanie zasobami ludzkimi w oparciu o kompetencje. Perspektywa uczenia się przez całe życie (2013) red. Sienkiewicz Ł., Warszawa, http://biblioteka-krk.ibe.edu.pl/ opac_css/doc_num.php?explnum_id=452 [data dostępu: 02.10.2013]

\section{Summary}

\section{Measurement and Analysis of Employee Absence}

Measuring the levels of absenteeism is one of main sources of key information used to assess the effectiveness of human resources management processes and measurement of human capital. The purpose of this article is to present - on the basis of the analysis of literature studies -the solutions used for measurement and analysis of employee absence volume level of the organization. Considerations are divided into four parts. The first one focuses on the discussion of the sources of information for the measurement and analysis of absenteeism. The next three parts relate to measurement and analysis of the level of absenteeism, its causes and costs.

Keywords: absence management, costs of absence, causes of absence, measuring absenteeism.

\section{Резюме}

\section{Измерение и анамиз неявок на работу}

Измерители, касающиеся неявок на работу, считаются ключевой информацией, используемой для оценки эффективности процессов управления человеческими ресурсами в организации, а также стоимости имеющегося в распоряжении человеческого капитала. Цель настоящей статьи - продемонстрировать, на основе проведенного анализа литературы, решения, применяемые в области измерения и анализа неявок на работуна уровне организации, а такжевозможности использования описанных показателей для оценки стоимости человеческого капитала. Рассуждения разделены на четыре части. В первой авторка сосредоточивается на обсуждении источников информации для измерения и анализа неявок на работу. Очередные три 
части касаются измерения и анализа соответственно: уровня неявок, их причин и связанных с ними расходов.

Ключевые слова: управление неявками; расходы, связанные с неявками; причины неявок; измерение неявок.

\section{Dr Małgorzata Striker}

Autorka jest adiunktem w Katedrze Zarządzania Zasobami Ludzkimi Uniwersytetu Łódzkiego. W pracy naukowej wykorzystuje kilkunastoletnie doświadczenie w zarządzaniu organizacjami. Jej zainteresowania koncentrują się wokół dwóch głównych zagadnień: wykorzystania instrumentów controllingu personalnego w praktyce oraz zarządzania w ochronie zdrowia. Dodatkowo uczestniczy w prowadzonych badaniach naukowych z zakresu zmian zachodzących na rynku pracy związanych z pokoleniem Y i wykorzystania e-learningu w edukacji dorosłych. 